\title{
Analysis of neomycin, kanamycin, tobramycin and amikacin resistance mechanisms in gentamicin- resistant isolates of Enterobacteriaceae
}

\author{
K. ADWAN, N. ABU-HASAN and H. AL-ASMAR \\ Department of Biological Sciences, An-Najah National University, Nablus, Palestine
}

\begin{abstract}
Twenty-four gentamicin-resistant isolates of Enterobacteriaceae, obtained from the clinical laboratories of three health centres in Nablus, Palestine, were tested for susceptibility to neomycin, kanamycin, tobramycin and amikacin. Resistance rates were $\mathbf{2 9 . 2 \%}$ for neomycin, $\mathbf{5 8 . 3} \%$ for kanamycin, $\mathbf{4 5 . 8 \%}$ for tobramycin and $\mathbf{8 . 3 \%}$ for amikacin. Fourteen $(58.3 \%)$ isolates were noted to be multiresistant, i.e., resistant to gentamicin and two or more other aminoglycosides; resistance to gentamicin, kanamycin and tobramycin was the most common pattern of multiple resistance. This pattern implies the involvement of adenyltransferase ANT(2")-I activity. Plasmid profiles and curing experiments suggested a plasmid localisation of gentamicin, neomycin, kanamycin and tobramycin resistance genes. However, a chromosomal location is proposed for plasmid-deficient strains. Cross-resistance in two isolates to all aminoglycosides tested suggested membrane impermeability to aminoglycosides as the mechanism of resistance.
\end{abstract}

\section{Introduction}

Aminoglycosides are used frequently for the treatment of life-threatening infections, although their clinical usefulness may be seriously hampered by the appearance of resistant strains. Among various resistance mechanisms, plasmid-mediated enzymic modification of the aminoglycoside molecule is clinically the most significant [1, 2]. Many of the genes encoding these modifying enzymes are also associated with transposons [2]. Antibiotic resistance frequencies and profiles seem to vary in different countries and are largely dependent on antibiotic prescribing policies $[3,4]$. The present study determined the mechanisms of resistance to neomycin, kanamycin, tobramycin and amikacin in gentamicin-resistant Enterobacteriaceae obtained from three health centres in Nablus, Palestine.

\section{Materials and methods}

\section{Bacteria}

Twenty-four gentamicin-resistant isolates of Enterobacteriaceae were obtained from clinical laboratories of three health centres in Nablus between April and July 1995. All were isolated from pathological samples

Received 4 Nov. 1997; revised version accepted 16 Feb. 1998.

Corresponding author: Dr K. Adwan. (urine, sputum, blood and umbilicus). Replicate isolates from the same patient were excluded. The collection of bacteria included Escherichia coli (10 isolates), Proteus spp. (4), Klebsiella spp. (5), Providencia spp. (2), Citrobacter spp. (1) and Enterobacter spp. (2).

\section{Susceptibility testing}

Antimicrobial susceptibilities of the isolates were determined by disk diffusion mainly as described by Bauer et al. [5]. Zones of inhibition to antibiotics were determined in accordance with the interpretive standards outlined by the National Committee for Clinical Laboratory Standards [6].

\section{Enzyme assay}

Crude extracts of 14 isolates resistant to gentamicin and two or more other aminoglycosides, were assayed for the presence of aminoglycoside adenylating and acetylating enzymes as described by Ono et al. [7]. Assays were performed with gentamicin as substrate. Prediction of aminoglycoside modifying enzyme types was inferred according to Shannon and Phillips [8].

\section{Plasmid isolation and curing}

Plasmids were isolated according to the method of Takahashi and Nagano [9]. Plasmids were cured by inoculating cultures grown overnight into Mueller- 
Hinton Broth (Oxoid) containing ethidium bromide (Sigma) $5-10 \mathrm{mg} / \mathrm{L}$ and incubating at $37^{\circ} \mathrm{C}$ for $48 \mathrm{~h}$. Appropriate dilutions of grown cultures were plated on Mueller-Hinton agar and colonies were replicated on to plates supplemented with gentamicin $20 \mathrm{mg} / \mathrm{L}$.

\section{Results}

The activity of four aminoglycosides (neomycin, kanamycin, tobramycin and amikacin) against gentamicin-resistant isolates was determined. Of the 24 isolates, $14(58.3 \%)$ were resistant to kanamycin, 11 $(45.8 \%)$ to tobramycin, $7(29.2 \%)$ to neomycin, and only $2(8.3 \%)$ to amikacin.

As is evident from Table 1, the most common enzyme

Table 1. Aminoglycoside resistance patterns and aminoglycoside modifying enzymes in 14 multi-resistant isolates

\begin{tabular}{|c|c|c|c|}
\hline Resistance pattern & $\begin{array}{l}\text { Number of } \\
\text { isolates }\end{array}$ & $\begin{array}{l}\text { Number of } \\
\text { organisms } \\
\text { with enzyme }\end{array}$ & $\begin{array}{c}\text { Inferred enzyme/ } \\
\text { resistance } \\
\text { mechanism* }\end{array}$ \\
\hline $\operatorname{Gen}^{r}, \operatorname{Kan}^{r}, \operatorname{Tob}^{r}$ & 7 & 6 & $\operatorname{ANT}\left(2^{\prime \prime}\right)-\mathrm{I}$ \\
\hline $\mathrm{Gen}^{r}, \mathrm{Neo}^{\mathrm{r}}, \mathrm{Kan}^{r}$ & 3 & 3 & $\mathrm{AAC}\left(6^{\prime}\right)-\mathrm{I}$ \\
\hline $\begin{array}{l}\mathrm{Gen}^{\mathrm{r}}, \mathrm{Neo}^{\mathrm{r}}, \mathrm{Kan}^{\mathrm{r}} \text {, } \\
\mathrm{Tob}^{\mathrm{r}}\end{array}$ & 2 & 2 & $\mathrm{AAC}(3)-\mathrm{IV}$ \\
\hline $\begin{array}{l}\mathrm{Gen}^{\mathrm{r}}, \mathrm{Neo}^{\mathrm{r}}, \mathrm{Kan}^{\mathrm{r}}, \\
\mathrm{Tob}^{\mathrm{r}}, \mathrm{Ami}^{\mathrm{r}}\end{array}$ & 2 & 0 & Impermeability \\
\hline Total & 14 & & \\
\hline
\end{tabular}

Gen, gentamicin; Neo, neomycin; Kan, kanamycin; Tob, tobramycin; Ami, amikacin.

*Inferences made on the basis of zones of inhibition produced by these compounds [8]. in multi-resistant isolates was inferred to be adenyltransferase $\mathrm{ANT}\left(2^{\prime \prime}\right)-\mathrm{I}$. In this bacterial collection, ANT $\left(2^{\prime \prime}\right)$-I was well represented in E. coli, Proteus and Klebsiella spp. In addition to ANT( $\left.2^{\prime \prime}\right)$-I enzyme, three isolates exhibited $\mathrm{AAC}\left(6^{\prime}\right)$-I and two showed evidence of AAC(3)-IV activity. Impermeabilitymediated resistance was inferred in two isolates.

Plasmid DNA isolation revealed various plasmids of $2-18 \mathrm{~kb}$. However, 12 of the gentamicin-resistant isolates did not contain discernible plasmids. Table 2 shows details of the plasmid profiles and antibiograms for the isolates. Six representative multi-resistant isolates were treated with ethidium bromide to cure plasmids. The loss of plasmids of 17 and $18 \mathrm{~kb}$ from isolates 12, 13 and 15, was closely associated with the loss of gentamicin resistance and adenylating activity. The loss of plasmids of 16 and $18 \mathrm{~kb}$ from isolates 18 and 21 , respectively, appeared to be associated with the loss of gentamicin resistance and acetylating activity. However, no loss of any resistance marker was observed when isolate 23 was treated with ethidium bromide.

\section{Discussion}

In this bacterial collection of 24 gentamicin-resistant Enterobacteriaceae, $14(58.3 \%)$ showed resistance to two or more of the clinically important aminoglycosides (Table 2). However, amikacin resistance was quite rare, as it was observed in only two of the multiresistant isolates. This probably reflects the increased usage of these antimicrobial agents, particularly

Table 2. Aminoglycoside susceptibility patterns and plasmid profiles in gentamicin-resistant Enterobacteriaceae

\begin{tabular}{|c|c|c|c|c|c|c|c|}
\hline \multirow[b]{2}{*}{ Isolate no. } & \multirow[b]{2}{*}{ Isolate } & \multicolumn{5}{|c|}{ Aminoglycoside susceptibility pattern } & \multirow{2}{*}{$\begin{array}{c}\text { Plasmid size } \\
(\mathrm{kb})\end{array}$} \\
\hline & & Gen & Neo & Kan & Tob & Ami & \\
\hline 1 & E. coli & $\mathrm{r}$ & $\mathrm{s}$ & $\mathrm{s}$ & $\mathrm{s}$ & $\mathrm{s}$ & 16 \\
\hline 2 & E. coli & $\mathrm{r}$ & $\mathrm{s}$ & $\mathrm{s}$ & $\mathrm{s}$ & s & None \\
\hline 3 & E. coli & $\mathrm{r}$ & $\mathrm{s}$ & $\mathrm{s}$ & $\mathrm{s}$ & s & 13,16 \\
\hline 4 & E. coli & $\mathrm{r}$ & s & $\mathrm{s}$ & $\mathrm{s}$ & s & 2,16 \\
\hline 5 & E. coli & $\mathrm{r}$ & $\mathrm{s}$ & $\mathrm{s}$ & $\mathrm{s}$ & $\mathrm{s}$ & None \\
\hline 6 & Proteus sp. & $\mathrm{r}$ & $\mathrm{s}$ & $\mathrm{s}$ & $\mathrm{s}$ & $\mathrm{s}$ & 13 \\
\hline 7 & Proteus sp. & $\mathrm{r}$ & $\mathrm{s}$ & $\mathrm{s}$ & $\mathrm{s}$ & $\mathrm{s}$ & None \\
\hline 8 & Klebsiella sp. & $\mathrm{r}$ & s & s & $\mathrm{s}$ & $\mathrm{s}$ & None \\
\hline 9 & Enterobacter sp. & $r$ & $\mathrm{~s}$ & $\mathrm{~s}$ & $\mathbf{s}$ & $\mathrm{s}$ & None \\
\hline 10 & Providencia sp. & $\mathrm{r}$ & $\mathrm{s}$ & $\mathrm{s}$ & $\mathrm{s}$ & $\mathrm{s}$ & None \\
\hline 11 & E. coli & $\mathrm{r}$ & $\mathrm{s}$ & $\mathrm{r}$ & $\mathbf{r}$ & $\mathrm{s}$ & $4,13,18$ \\
\hline 12 & E. coli & $\mathrm{r}$ & s & $\mathrm{r}$ & $r$ & $\mathrm{~s}$ & 2,17 \\
\hline 13 & Proteus sp. & $\mathrm{r}$ & s & $\mathrm{r}$ & $\mathrm{r}$ & s & 18 \\
\hline 14 & Proteus sp. & $\mathrm{r}$ & $\mathrm{s}$ & $\mathrm{r}$ & $r$ & s & None \\
\hline 15 & Klebsiella sp. & $r$ & $\mathrm{~s}$ & $\mathrm{r}$ & $r$ & $\mathrm{~s}$ & 17 \\
\hline 16 & Klebsiella sp. & $\mathrm{r}$ & s & $\mathrm{r}$ & $r$ & $\mathrm{~s}$ & None \\
\hline 17 & Citrobacter sp. & $\mathrm{r}$ & $s$ & $\mathrm{r}$ & $r$ & $\mathrm{~s}$ & None \\
\hline 18 & E. coli & $\mathbf{r}$ & $\mathrm{r}$ & $\mathbf{r}$ & s & $\mathrm{s}$ & 3,16 \\
\hline 19 & Klebsiella sp. & $\mathrm{r}$ & $\mathrm{r}$ & $\mathrm{r}$ & $\mathrm{s}$ & $\mathrm{s}$ & None \\
\hline 20 & Enterobacter sp. & $\mathrm{r}$ & $\mathrm{r}$ & $r$ & $\mathrm{~s}$ & $\mathrm{~s}$ & 4,5 \\
\hline 21 & E. coli & $\mathrm{r}$ & $r$ & $\mathrm{r}$ & $r$ & $\mathrm{~s}$ & 16,18 \\
\hline 22 & Klebsiella sp. & $\mathrm{r}$ & $\mathrm{r}$ & $\mathrm{r}$ & $r$ & $\mathrm{~s}$ & None \\
\hline 23 & E. coli & $\mathrm{r}$ & $\mathrm{r}$ & $\mathrm{r}$ & $\mathrm{r}$ & $\mathrm{r}$ & 16 \\
\hline 24 & Providencia sp. & $r$ & $\mathrm{r}$ & $\mathrm{r}$ & $r$ & $\mathrm{r}$ & None \\
\hline
\end{tabular}

Gen, gentamicin; Neo, neomycin; Kan, kanamycin; Tob, Tobramycin; Ami, amikacin. 
gentamicin, in treating infections with enterobacteria in these health centres (personal communications). As a result of these findings, performing a periodic replacement of the first-line aminoglycoside for which resistance has become apparent - such as the use of amikacin as the primary aminoglycoside while the use of others is restricted - should be considered as a way of controlling aminoglycoside resistance, particularly enzyme-mediated resistance. Resistance to gentamicin, kanamycin and tobramycin appeared to be the common multi-resistance pattern. This resistance pattern seemed to be related to the presence of adenyltransferase $\operatorname{ANT}\left(2^{\prime \prime}\right)-\mathrm{I}$ activity. In addition, three isolates exhibited AAC $\left(6^{\prime}\right)-\mathrm{I}$, which confers resistance to gentamicin, neomycin and kanamycin, and two isolates showed evidence of AAC(3)-IV activity. The occurrence of the ANT(2")-I, AAC(6')-I and AAC(3)-IV mechanisms in gentamicin-resistant Enterobacteriaceae has been reported previously [1].

The results suggest a plasmid localisation of resistance genes in the isolates harbouring plasmids, as in all isolates subjected to cure of plasmids, gentamicin resistance and adenylating or acetylating activity were lost. On the other hand, chromosomal location is proposed for plasmid-deficient resistant isolates. Both chromosomal and plasmid-mediated resistance have been reported in the same outbreak, which suggests the involvement of transposons bearing resistance genes and able to integrate into both plasmids and the chromosome [10].

The broad aminoglycoside resistance pattern shown by isolates 23 and 24 suggests chromosomally mediated reduction in uptake of aminoglycosides - although isolate 23 did contain a $16-\mathrm{kb}$ plasmid which might have accounted for gentamicin resistance, curing was not associated with loss of resistance. Aminoglycoside cross-resistance, including amikacin, in various clinical settings has been shown to be due to a permeability barrier in the bacterial cells, a resistance phenotype which mitigates against therapeutic use of any aminoglycoside $[1,11]$.

In conclusion, these findings underscore the need for more detailed epidemiological studies, including a careful programme of isolating and following all patients colonised or infected with aminoglycosideresistant Enterobacteriaceae. Such a study will be of great value for understanding the mechanisms behind the emergence of such resistance.

\section{References}

1. Kallova J, Macickova T, Majtanova A, Aghova A, Adam D, Kettner M. Transferable amikacin resistance in gram-negative bacterial isolates. Chemotherapy 1995; 41: 187-192.

2. Shaw KJ, Rather PN, Hare RS, Miller GH. Molecular genetics of aminoglycoside resistance genes and familiar relationship of the aminoglycoside-modifying enzymes. Microbiol Rev 1993; 57: $138-163$.

3. Gordon AM. Gentamicin resistant Klebsiella strains in a hospital. BMJ 1980; 280: 722-723.

4. Adwan KM, Kocabiyik S, Alaeddinoglu NG. Effect of drug usage on aminoglycoside susceptibilities of Pseudomonas aeruginosa isolates. Int $J$ Exp Clin Chemother 1990; 3: 179-183.

5. Bauer AW, Kirby WMM, Sherris JC, Turck M. Antibiotic susceptibility testing by a standardized single disk method. Am $J$ Clin Pathol 1966; 45: 493-496.

6. National Committee for Clinical Laboratory Standards. 1993. Performance standards for antimicrobial disc susceptibility tests: tentative standards, vol 3, no. 24, NCCLS document M2-A5. Villanova, PA, National Committee for Clinical Laboratory Standards.

7. Ono H, Crameri R, Hintermann G, Hutter R. Hydroxystreptomycin production and resistance in Streptomyces glaucescens. $J$ Gen Microbiol 1983; 129: 529-537.

8. Shannon K, Phillips I. Mechanisms of resistance to aminoglycosides in clinical isolates. J Antimicrob Chemother 1982; 9: $91-102$.

9. Takahashi S, Nagano Y. Rapid procedure for isolation of plasmid DNA and application to epidemiological analysis. $J$ Clin Microbiol 1984; 20: 608-613.

10. Townsend DE, Grubb WB, Ashdown N. Gentamicin resistance in methicillin-resistant Staphylococcus aureus. Pathology 1983; 15: $169-174$

11. McNeill WF, John JF, Twitty JA. Aminoglycoside resistance in Pseudomonas aeruginosa isolated from cystic fibrosis patients. Am J Clin Pathol 1984; 81: 742-747. 